\title{
KatarzYNa GóRAK-SOSNOWSKA*
}

\section{The COVID-19 Pandemic in the Middle East and North Africa. Old Demons in a New Bottle}

\begin{abstract}
The paper presents the strategies of Middle East and North African countries in coping with COVID-19 pandemic in the first months of spring/summer 2020. It offers a categorisation of strategies basing on the available assets the countries have and political situation. According to this categorisation there are countries in which the pandemic is one more burden to bear that makes the current political or economic situation even worse (countries torn by war or serious internal social conflicts); countries that cope with the pandemic as good as it gets - taking their institutional capacities (Egypt and Morocco); the too rich to fail category of GCC countries, and two possible success stories (by that time Jordan and Tunisia).
\end{abstract}

Key words: Middle East and North Africa, COVID-19, pandemic.

JEL Classification: Z00.

\section{Introduction}

It is not hard to guess that djinns rather than demons inhabit bottles, according to one of the tales of the One Thousand and One Nights. However, while djinns are not inherently good or bad, the demons are known to be evil, and thus they better

\footnotetext{
* SGH Warsaw School of Economics, kgorak@sgh.waw.pl; ORCID: 0000-0002-1121-
} 6240. 
reflect the consequences of managing the COVID-19 pandemic in the Arab countries of the Middle East and North Africa (MENA). The global pandemic has challenged the whole world twofold. On one hand, it had exposed all the social, economic and political ills of the countries exposed to the virus. Whichever miseries had been afflicting the peoples of MENA countries, one can be certain that the pandemic will only deepen them. On the other hand, it has provided an opportunity for some governments to prove their capabilities in responding to this disaster and improve their ratings nationally or internationally.

This paper aims to present an overview of the existing challenges and response strategies of Arab MENA countries to the global COVID-19 pandemic in the beginning of spring/summer of 2020. Despite that fact that the pandemic has been affecting the region for several months, so a relatively short period of time, it is possible to determine different types of reactions to this crisis. One core characteristic of the region makes these estimations possible, namely a relative resistance to change and a fixed set of resources that each country has. This relative resistance to change has been visible since the unprecedented wave of dynamic and wideranging socio-political movements which are known as the Arab Spring. Despite high hopes for a meaningful political change, it has only brought a turmoil to the affected countries and/or has strengthened the authoritarian rule (with Tunisia being the sole and troublesome exception). Therefore, it is doubtful whether the region will soon be able to produce any other political movement of a similar scope and impact, especially as all the efforts seem to have been in vain. In other words, regardless of the copying strategy adapted in MENA countries due to the pandemic, most likely none of the governments will be challenged by their societies.

\section{Can Authoritarian Rule Pay Off?}

One of the most prevalent questions that have arisen with the pandemic is when (and whether) it will end. One of the issues that have been discussed widely is whether democratic or authoritarian regimes handle pandemics better. While some Western authors turn to the democratic model, even if it has provided mixed results (Kleinfeld 2020), it seems that some authoritarian regimes can also achieve their goals. This is not a universal rule, as the available data does not offer a promising correlation between the nature of governments and the impact of COVID-19 (Jaishankar 2020). Still, it seems that other factors than political system influence the way governments 
can handle the pandemics. Rachel Kleinfeld identified three such factors: lessons learnt from previous pandemic experience (especially SARS), legitimate political system and capabilities to respond (Kleinfeld 2020). While no MENA country has been seriously affected by SARS in the past, the two other factors can explain, in great detail, how MENA countries reacted to the pandemic and why their response was often efficient.

By the end of June, the MENA region has been affected with the global COVID-19 pandemic in different ways and manners, as the table below presents.

Table 1: Total cases and recent cases in MENA countries as of 30.06.2020

\begin{tabular}{|l|c|c|c|}
\hline & Population (thousands) & Total cases & Recent new a day \\
\hline Algeria & 43.851 & 12.445 & 151 \\
\hline Bahrain & 1.701 & 24.081 & 1.527 \\
\hline Egypt & 102.334 & 61.129 & 1.917 \\
\hline Iraq & 40.222 & 39.139 & 12 \\
\hline Jordan & 10.200 & 1.086 & 673 \\
\hline Kuwait & 4.270 & 42.788 & 23 \\
\hline Lebanon & 6.825 & 1.661 & $?$ \\
\hline Libya & 6.871 & & 323 \\
\hline Morocco & 36.910 & 11.338 & 1.154 \\
\hline Oman & 5.101 & 34.902 & 1.056 \\
\hline Qatar & 2.881 & 91.838 & 3.521 \\
\hline Saudi Arabia & 34.813 & 170.639 & $?$ \\
\hline Syria & 17.500 & & $?$ \\
\hline Tunisia & 11.818 & 1.162 & 4 \\
\hline UAE & 9.890 & 46.554 & 401 \\
\hline Yemen & 29.825 & $?$ & $?$ \\
\hline
\end{tabular}

Source: Countries beating Covid-19, EndCoronavirus.org, https://www.endcoronavirus.org/countries.

Most of the COVID-19 cases are in the oil rich GCC countries, with Saudi Arabia having the highest number of infected, followed by Qatar. Egypt, the most populous Arab country, occupies the third position, but the number of cases is only one third of the number in Saudi Arabia. Comparing to the size of local population, Bahrain, Kuwait and Oman also score high in total number of cases. Small and poorer Arab countries - Jordan, Lebanon and Tunisia - have less than 2 thousand total cases, and the spread of the virus seems to be limited.

Regardless of capabilities to manage the coronavirus crisis most of the countries adapted a strict policy response aimed at minimalizing the spread of the virus, as illustrated on the Figure 1 below. The measurement applied here is the stringency 
level, which reflects the level of how strict the measures imposed by the countries were. The graph aims to present a general trend in the region, with a few exceptions of countries that applied less strict measures or applied them later.

Figure 1: Calculated stringency level (0-100) of MENA governments from 1.02.2019 to 30.06 .2019

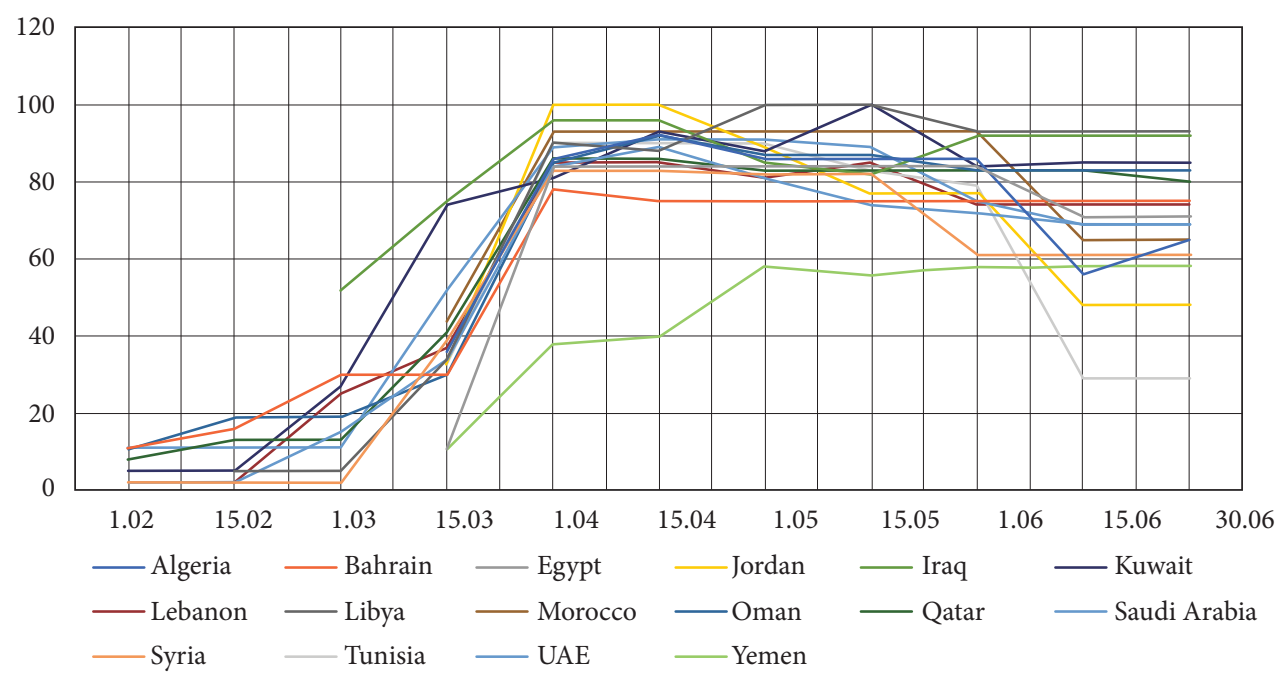

Source: Own elaboration based on data from https://covidtracker.bsg.ox.ac.uk/stringency-scatter.

At some point three countries (Jordan, Kuwait and Libya) adopted the most strict set of policies to limit the spread of the virus, consisting of: containment and closure (school closing, workplace closing (except for essential), cancelling public events, restrictions on gatherings, closing public transport, stay at home requirements, restrictions on internal movement, border closure) and health systems (public information campaign) (Hale, Angrist, Patherick, Phillips, Webster 2020, 5). The other countries were close to follow. The only exception was Yemen, which has been torn by the ongoing civil war. Interestingly only two countries - Tunisia and Jordan - significantly limited the stringency level around mid-June. Other Arab MENA countries have limited it only slightly or maintained it on a high level. Taking into account the uneasy global situation with the second wave of pandemic to be expected around the autumn of 2020, maintaining high stringency can be understandable. At the same time, as the vast majority of MENA countries fit the definition of authoritarian regimes (of various types and flavours), one can suspect that once adapted, some measures might not be easy to remove. 
Despite cultural similarities, there are many differences within the region. While the reaction of most countries to the pandemic was similar, it differed in the two aspects named above - legitimation of the governments to manage the pandemic, and capabilities to produce a reasonable crisis response. Below one can find a typology of MENA countries in regard to these two dimensions. It starts with a set of countries that enjoy no legitimacy from their citizens, as they belong to the so-called fragile states, and thus have no capabilities to react. The second category has limited capabilities to react and very limited legitimacy for its policy response. Thus, there is a potential for social protests. The third category consists of countries that have limited capacities and somewhat stronger legitimacy for implementing their policies. The next one has it all - huge capabilities and, mostly, strong legitimacy. The last category comprises countries that have limited capabilities, but strong legitimacy, which has made them a success story for the whole region.

\section{One More Burden to Bear: Libya, Syria and Yemen}

Taking into account the civil wars that have been choking Libya, Syria and Yemen in the last years, Covid-19 ranks relatively low on the local lists of natural and humanitarian disasters. The societies have been drained by local wars, while their countries - destroyed. In other words, there are neither capacities to react to the pandemic, nor legitimacy of the governments, as they are fighting for their cause with rival governments, militias or foreign stakeholders.

The war in Yemen, conducted by Houthi rebels against the government supported by Saudi-led coalition had cost the lives of more than 112 thousand people, including over 12 thousand civilians who died in targeted attacks (Acled Resources: War in Yemen 2020). Soon the ongoing conflict that serves as a proxy war between Saudi and Iranian forces became unbearable to a huge number of Yemeni citizens. While the country has been ranked among the poorest countries in the MENA region in terms of GDP per capita, the civil war brought famine to the country and over half of its population is at risk of malnutrition (Talmazan 2018). Soon the poor health and sanitation infrastructure damaged by war brought another disaster - an outbreak of cholera that began in late 2016. As of the autumn of 2019 the number of suspected cases stood at 2,2 million, while 3,8 thousand people have died (World Health Organisation 2019). Comparing to the other disasters, the Covid-19 pandemic seems to be just one more burden to bear. However, taking into account the death rate 
reported at 255 and the number of reported cases - 926 as of June 2020 (reliefweb.int 2020a), one can see that the virus is much more harmful and deadlier than elsewhere. Devastation of the country's infrastructure made the simplest measures to prevent the pandemic impossible, as the health care and sanitation system collapsed, and even access to clean water is very limited. The vast majority of Yemeni population (about $80 \%$ ) depends on aid to survive, which makes them even more vulnerable to any illness (BBC 2020). Moreover, the 926 cases are most likely highly underreported - during a civil war testing citizens against coronavirus comes low on the list of priorities.

While the Libyan civil war has started in 2014 the country had been unstable since the collapse of the Mu'ammar al-Kaddafi regime in 2011. Despite political and military efforts no force was able to reunite the whole country, which has been divided between two opposing forces - those of the House of Representatives and the Libyan National Army and those of the Government of National Accord with the Libya Shield Force, and additionally - by local militias. Years of a multilateral civil war have already put the healthcare system at the verge of collapse. What is more, the conflicted forces have not only decided to continue and intensify their fight, but also have been targeting health facilities (reliefweb.int 2020b).

In a similar manner a civil war has been going on in Syria since 2011, along with demonstrations against the rule of Syrian president Bashar al-Asad. Becoming a proxy war of different countries and agents, and for several years the core part of the self-proclaimed caliphate of the Islamic State, Syria has turned into the deadliest war zone of the $21^{\text {st }}$ century, with over 0,5 million people killed (Syrian Observatory for Human Rights 2020), over 7,6 million internally displaced and over 5,1 million refugees (UNHCR 2020). While the number of confirmed Covid-19 cases has been low - just 58 as for May 2020 - the number can be underestimated, as only two out of three hospitals in the country are fully functioning, and medical and protective equipment is in short supply (reliefweb.int 2020c).

\section{Too Much to Bear: Algeria, Iraq and Lebanon}

The pandemic has caught at least three MENA countries in an already unstable political situation. Citizens of Algeria, Iraq and Lebanon were protesting against their ineffective governments, hoping for a political change. Thus, their countries have some (although limited) capacities to respond to the pandemic, but the legitimacy of the governments is at stake. 
Algerian protesters have formed the Hirak Movement and started their activity by demanding a resignation of Abd Al-Aziz Al-Boutaflika, who has just stated that he was going to apply for the $5^{\text {th }}$ presidential term. While this has ultimately been achieved in spring, the Hirakis kept protesting every week demanding more democracy, civic liberties, rule of law and getting rid not only of the president, but also from the ruling clans and groups of the regime. The Covid-19 pandemic has limited Hirak's activity - they decided to discontinue the protest by mid-March for the sake of collective health. At the same time the Algerian government has used the opportunity to stop the movement by intensifying arrests against its members, journalists and activists. Moreover, a law that criminalises dissemination of fake news has been adopted, which in this harsh political context can serve as a legitimisation of government attempts to crush the Hirakis (Middle East Monitor 2020). It seems that the pandemic has been used for political purposes, but - taking into account the scope of social discontent - one cannot be sure, whether these strict measures will bring any long-lasting political result.

The Lebanese protests started only several months later and were triggered by harsh economic situation. New taxes (for gasoline, tobacco, some applications) provoked people to demonstrate against high unemployment, sectarian rule and ineffective government (Daily Star 2019). The protests led to the resignation of the prime minister Saad Hariri and appointment of a new one - Hassan Diab. However, the demonstrations have been continued as the new government has not met the hopes and the economic situation has not been improved. An additional challenge has been the debt that the country had to manage and pay to its international creditors. As if the situation had not been severe enough, the pandemic has hit the country causing many businesses to close. In April the protests intensified in terms of scale, size and force used. As of the end of June a new wave of protests has been going on in Lebanon, and the Lebanese pound has lost 70\% of its value from October 2019 (BBC News 2020). As any plan for a bailout will have to involve economic reforms that will be hard to bear for the society, there seems to be no way out. What is more, the Covid-19 has actually only exacerbated the troublesome situation of the country.

Iraq is a country that seems to be finally recovering from the years of civil war and the dominance of the so-called Islamic State. While IS has been expelled from Iraqi territory around 2017, there has been an ongoing low-level insurgency on its territory, inspired and incited by a number of military and paramilitary forces of different loyalties. At the same time the country has been witnessing ongoing civil protests against ineffective economic policy, inefficient public services, corruption and state violence. Just as in the case of Lebanon, the protests have resulted in 
a change of government with three designated prime ministers in 10 weeks trying to pass a new government (Reuters 2020). Despite the pandemic, people kept protesting as the economic and political situation of their country gave them no hope. Still, it is questionable whether the country will be able to recover from the war in a way that would be acceptable for its citizens.

\section{As Good as it Gets: Egypt and Morocco}

In comparison with other Arab states Egypt and Morocco share similar socioeconomic conditions with high proportion of rural population, low GDP, low education and young age. Although they differ in terms of political system, as Egypt is a republic, doomed to be authoritarian after the collapse of the rule of Muhammad Mursi, while Morocco is a monarchy, which can be strict to its citizens if needed, they have taken similar approaches to the COVID-19 pandemic.

The health care systems in both countries are understaffed and underpaid with just 7 physicians per 10 thousand people (WHO 2020). It may not be the lowest in the region, as the poorest country is Yemen, but rather worse than better, and definitely below the average for MENA countries, even if the high-income countries are excluded. The scarce resources make managing the pandemic even more problematic, as the chances that the number of infected who need hospital treatment will exceed the capacity of health institutions is relatively high. Thus, both countries developed a strategy of surveillance with high stringency level aimed at limiting physical contact and so hoping to flatten the deadly COVID-19 curve.

The way Morocco has been dealing with COVID-19 has been praised by some and criticized by others. The country has closed its borders relatively quickly, prepared hospitals and set production of masks, medical equipment and devices, mostly by local companies (North Africa Post 2020). While wearing masks is obligatory, the authorities made them affordable by a subsidised price of 0,08 USD. Early and stringent measures were necessary, as the health care system has a limited capacity. Strict lockdown, medical protocols, limited travel, but also enforcing lockdown by police and soldiers, as well as arrests for disobedience have definitely limited the spread of the virus. The strictness of these measures (28 thousand people have been arrested since in one month for disobedience) (Middle East Eye 2020) and the newly imposed laws can be used against any political discontent (not just related to the pandemic) (Moceri 2020). 
Egypt has also tried to manage pandemic with a heavy hand, however the results have been less impressive. While it has also established an emergency fund and announced a closure of public institutions and businesses, followed by a curfew, all these actions had been done only by mid-March. The health care system is overloaded, with some people being denied entry to the hospital, and there have been only 135 thousand tests made in a country of 100 million inhabitants (İnanç 2020). In fact, a lot of effort has been put on maintaining a proper media narrative. Thus, not only Egyptians were arrested for spreading fake news about the pandemic, but also foreign journalists banned or censored (Mezran, Melcangi, Burchfield, Riboua 2020). It seems that the government has used the pandemic to gain new powers, as only some of the recent amendments to the Emergency Law are clearly related to COVID-19 (El-Sisi 2020).

\section{Too Rich to Fail: the Oil Rich GCC Countries}

The oil abundant countries of GCC have been marked by a high number of recorded cases, combined with strict policy measures and extensive health care. The high number of recorded cases in GCC countries results from a high proportion of foreign low-paid labour workers who live in overcrowded camps. Low quality of medical care available for this group and relatively low standards of living increase the chances of transmission of the virus (Tadros 2020). In fact, Saudi Arabia, followed by Qatar, has the highest rate of active cases among Arab countries, while other GCC countries also rank high with more cases only in the two most populous Arab countries - Egypt and Iraq. At the same time, the GCC health care system combined with a relatively young and healthy migrant population made the death rate relatively low.

The GCC countries adopted a cautious, but at the same time strict policy against the pandemic. Policy measures included curfews, travel bans, and in the case of the Kingdom of Saudi Arabia - suspension of entry to Mecca, including limiting hajj only to Saudi nationals and residents. In cities or areas with a high coronavirus rate a 24 hour curfew has been imposed (Naar 2020), or the entire areas were cut off, as in the case of some migrant camps. The strictest measures were imposed in Kuwait, including a full curfew starting in May 2020. Citizens were only allowed to go out for 2 hours a day, and only within their neighbourhoods, as cars were banned from use (KUNA 2020). An important element of these measures was surveillance. In UAE 
spreading false information about the pandemic was introduced into the criminal code, while in Oman some people were persecuted for spreading fake news about the pandemic (Oman Observer 2020). In Bahrain those who tested positively were requested to wear electronic tags (Toumi 2020). In Oman movement and spreading of COVID-19 is being tracked and monitored by an application that is also used to detect symptoms and trace contact to those who got infected (WHO 2020b).

With the drop of oil prices some of the GCC countries had to impose austerity measures to ease the burden of severe budget deficits. In the case of Saudi Arabia, the country has tripled the VAT rate to $15 \%$, suspended the cost of living allowance for state employees and decided to cut off some parts of the Vision 2030 programme for a total amount of 26,6 bn USD (Aljazeera 2020). Other GCC countries follow this pattern and impose fiscal measures that impact their citizens, and the rentier state model has been significantly challenged (Nereim,. Westall 2020).

\section{Towards a Success Story: Jordan and Tunisia}

While it is still too early to say that any MENA country has ultimately won the battle against COVID-19, it seems that two countries are on the right path - Tunisia and Jordan. One is the only democracy that had emerged after the Arab Spring of 2011, and the other is one of the two liberal Arab monarchies.

Tunisia was the only MENA country to be officially nearly free from the COVID-19 virus with no active cases. The country has just opened its borders hoping for foreign tourists to support its national economy. Tunisia's strategy against the virus has been effective by combining adoption of early measures such as a comprehensive lockdown, testing and surveillance (Alinson 2020). Opening the borders was not an easy decision. On one hand the strategy adopted by Tunisian government proved to bring results, as the number of recorded cases had been relatively low. On the other hand, there have been protests and demonstrations against high unemployment, inflation and corruption - challenges that have been a permanent burden of every Tunisian government since the Arab Spring.

Jordan has been named as one of COVID-19 success stories mostly due to the early adoption of strict measures in order to prevent spreading the virus as early as 5 weeks before the first confirmed case. Jordanian strategy included preparing selected health facilities for treatment of COVID-19 patients, as well as a lockdown enforced by a set of emergency military laws, one of the strictest in the whole region. 
They included not only closing schools, businesses and government offices, but also a curfew from $6 \mathrm{pm}$ to $10 \mathrm{am}$ and prohibition of using vehicles. These measures combined with testing 2-3.000 people daily made it possible to limit the spread of the virus (Ward 2020).

\section{Conclusions}

The countries of MENA region have approached the Covid-19 pandemic in a similar manner, by employing the measures that they have used before - surveillance of citizens, strict containment, a closure of public activities and provision of health care as much as possible. The citizens have been enduring authoritarian rule of their governments for decades. Some of them wanted more freedom, but the bulk of Arab citizens seem to be content with their political leaders. In case of a new emergency, the Arab regimes have turned to the ways of managing them that will have the best possible result. Moreover, it seems that this strategy has proven to be effective. Of course, one has to take into account the young age of Arab population, which makes them less susceptible to the virus. One may also observe to how the global pandemic will affect Arab economies, many of which depend of tourism. At the same time, it seems that Arab populations have rather obeyed the regulations and followed the rules, despite the collective character of these societies and Ramadan that has been underway.

In case of the fragile Arab states - Yemen, Libya and Syria - it is of course hard to speak about any reasonable measures that these countries could take in order to limit the spread of the virus. In case of other states in MENA region, the high stringency level seemed to be working as good as it can. The GCC countries have high level of recorded cases, but the death rate is very low. There are some countries which despite poorly equipped health care managed to significantly flatten the curve. Tunisia and Jordan are two countries that have been praised for their efforts in limiting the spread of Covid-19. Except for the fragile states, only several countries seem to be less effective in the battle - Iraq, Lebanon, or Egypt, countries with a low level of trust in government, or those with a relatively clumsy approach to the virus. However, the battle is not always against the virus itself (at least not yet), but rather a part of an ongoing political struggle. 


\section{References}

Acled Resources: War in Yemen, https://acleddata.com/2020/03/25/acled-resources-war-inyemen/.

Aljazeera. 2020. Saudi Arabia to impose 'painful' austerity measures, triple VAT, Aljazeera, 11.05.2020, https://www.aljazeera.com/ajimpact/saudi-arabia-impose-painful-austeritymeasures-triple-vat-200511040647800.html [accessed on: 19.10.2020].

Alinson T. 2020. Tunisia nears zero coronavirus cases as it eyes tourism, Deutsche Welle, 13.06.2020, https://www.dw.com/en/tunisia-economy-hopes-for-tourists-after-coronavirus/a-53790180 [accessed on: 19.10.2020].

BBC. 2020. Coronavirus: Five reasons why it is so bad in Yemen, 21.06.2020, https://www.bbc. com/news/world-middle-east-53106164 [accessed on: 19.10.2020].

BBC News. 2020. Lebanon protests: Hundreds take to streets for second night, 13.06.2020, https:// www.bbc.com/news/world-middle-east-53031683 [accessed on: 19.10.2020].

Daily Star. 2019. Lebanese govt to charge $\$ 0.20$ a day for WhatsApp calls, 17.10.2019, http:// www.dailystar.com.lb/News/Lebanon-News/2019/Oct-17/493723-lebanon-to-charge-6-onwhatsapp-call-report.ashx [accessed on: 19.10.2020].

El-Sisi A. 2020. Egypt's el-Sisi expands powers, citing coronavirus pandemic, Aljazeera, 9.05.2020, ihttps://www.aljazeera.com/news/2020/05/egypt-el-sisi-expands-powers-citing-coronaviruspandemic-200509070706295.html [accessed on: 19.10.2020].

Hale T., Angrist N., Patherick A., Phillips T., Webster S. 2020. Variation in government responses to COVID-19, BSG Working Paper Series, Blavatnik School of Government, University of Oxford, May 2020.

İnanç Y. 2020. Egypt fails to cope with COVID-19 under El-Sisis' regime, Daily Sabah, 27.05.2020, https://www.dailysabah.com/world/mid-east/egypt-fails-to-cope-with-covid-19-under-elsissis-regime [accessed on: 19.10.2020].

Jaishankar D. 2020. What does COVID-19 tell us about democracy vs authoritarianism?, Observer Research Foundation, 16.05.2020, https:/www.orfonline.org/expert-speak/what-doescovid19-tell-us-about-democracy-vs-authoritarianism-66228/ [accessed on: 19.10.2020].

Kleinfeld R. 2020. Do Authoritarian or Democratic Countries Handle Pandemics Better?, Carnegie Endowment for International Peace, 31.03.2020, https://carnegieendowment.org/2020/03/31/ do-authoritarian-or-democratic-countries-handle-pandemics-better-pub-81404 [accessed on: 19.10.2020].

KUNA. 2020. Kuwait in full curfew May 10, public allowed to exercise two hours daily - gov't, 8.05.2020, https://www.kuna.net.kw/ArticleDetails.aspx?id=2891867\&language=en [accessed on: 19.10.2020]. 
Mezran K., Melcangi A., Burchfield E., Riboua Z. 2020. The coronavirus crisis highlights the unique challenges of North African countries, Atlantic Council, 30.03.2020, https://www. atlanticcouncil.org/blogs/menasource/the-coronavirus-crisis-highlights-the-uniquechallenges-of-north-african-countries/ [accessed on: 19.10.2020].

Middle East Eye. 2020. Morocco arrests thousands for breaching emergency rules, 14.04.2020, https://www.middleeasteye.net/news/coronavirus-morocco-arrests-thousands-breachingemergency-rules [accessed on: 19.10.2020].

Middle East Monitor. 2020. Algeria using COVID-19 to quash anti-government protests, 12.05.2020, https://www.middleeastmonitor.com/20200512-algeria-using-covid-19-to-quashanti-government-protests/ [accessed on: 19.10.2020].

Moceri A. 2020. Morocco is a COVID-19 success story. But at what cost? World Politics Review, 15.06.2020, https://www.worldpoliticsreview.com/articles/28840/in-morocco-human-rightsdeteriorate-amid-a-strict-covid-19-response [accessed on: 19.10.2020].

Naar I., Coronavirus: Saudi Arabia imposes 24-houe curfew in several cities, including Riyadh, Al-Arabiyya, 6.04.2020, https://english.alarabiya.net/en/News/gulf/2020/04/06/CoronavirusSaudi-Arabia-imposes-24-hour-curfew-in-several-cities-including-Riyadh.html [accessed on: 19.10.2020].

North Africa Post. 2020. COVID-19: Morocco's impressive management of the crisis stands as a model - France Soir, 3.05.2020, https://northafricapost.com/40563-covid-19-moroccosimpressive-management-of-the-crisis-stands-as-a-model-france-soir.html [accessed on: 19.10.2020].

Nereim V., Westall S. 2020. Crisis Austerity in Oli-Rich Gulf May test Political Balance, Bloomberg, 3.06.2020, https://www.bloomberg.com/news/articles/2020-06-03/austerity-experiment-inoil-rich-gulf-may-falter-post-crisis [accessed on: 19.10.2020].

Oman Observer. 2020. Some people detained for spreading fake news, 21.03.2020, https:// www.omanobserver.om/some-people-detained-for-spreading-fake-news/ [accessed on: 19.10.2020].

Reliefweb.int. 2020a. Yemen COVID=19 Preparedness and Response Snapshot - as of 20 June 2020 [EN/AR], OCHA, 22.06.2020, https://reliefweb.int/report/yemen/yemen-covid-19preparedness-and-response-snapshot-20-june-2020-enar [accessed on: 19.10.2020].

Reliefweb.int. 2020b. Libya COVID-19 cases double in 14 days as violence increases, exacerbating existing threats facing vulnerable populations, IRC, 12.06.2020, https://reliefweb.int/report/ libya/libya-covid-19-cases-double-14-days-violence-increases-exacerbating-existing-threats [accessed on: 19.10.2020].

WHO. 2019. Cholera Situation in Yemen.

WHO. 2020. World Health Organization's Global Health Workforce Statistics, OECD, supplemented by country data, https://data.worldbank.org/indicator/SH.MED.PHYS. 
ZS? end $=1982 \&$ name_desc $=$ false $\&$ start $=1982 \& v i e w=$ bar $\&$ year $=2017$ [accessed on: 19.10.2020].

WHO. 2020b. Using technology to contain COVID-19 in Oman, 17.06.2020, http://www.emro. who.int/health-topics/corona-virus/using-technology-to-contain-covod-19-in-oman.html [accessed on: 19.10.2020].

UNHCR. 2020. Syria Regional Refugee Response, 11.06.2020, https://data2.unhcr.org/en/ situations/syria [accessed on: 19.10.2020]. 